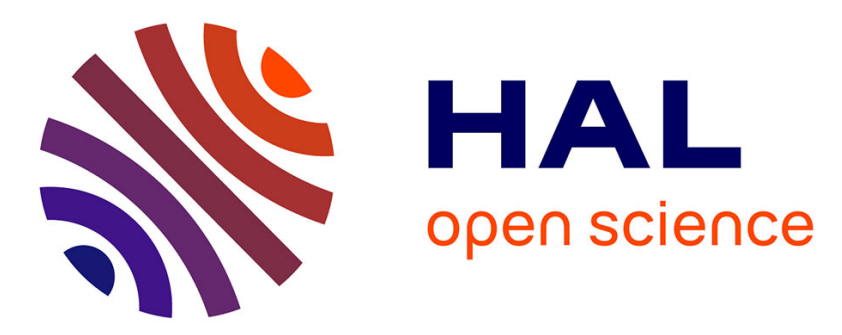

\title{
History of the Use of Computers and Information Technology in Education in Universities and Schools in Victoria
}

Arthur Tatnall, Bill Davey

\section{- To cite this version:}

Arthur Tatnall, Bill Davey. History of the Use of Computers and Information Technology in Education in Universities and Schools in Victoria. 11th IFIP International Conference on Human Choice and Computers (HCC), Jul 2014, Turku, Finland. pp.214-225, 10.1007/978-3-662-44208-1_18 . hal01383059

\section{HAL Id: hal-01383059 \\ https://hal.inria.fr/hal-01383059}

Submitted on 18 Oct 2016

HAL is a multi-disciplinary open access archive for the deposit and dissemination of scientific research documents, whether they are published or not. The documents may come from teaching and research institutions in France or abroad, or from public or private research centers.
L'archive ouverte pluridisciplinaire HAL, est destinée au dépôt et à la diffusion de documents scientifiques de niveau recherche, publiés ou non, émanant des établissements d'enseignement et de recherche français ou étrangers, des laboratoires publics ou privés.

\section{(c)(1)}

Distributed under a Creative Commons Attribution| 4.0 International License 


\title{
History of the Use of Computers and Information Technology in Education in Universities and Schools in Victoria
}

\author{
Arthur Tatnall $^{1}$, Bill Davey ${ }^{2}$ \\ ${ }^{1}$ Victoria University, Melbourne, Australia, \\ ${ }^{2}$ RMIT University, Melbourne, Australia \\ Athur.Tatnallevu.edu.au, Bill.Davey@rmit.edu.au
}

\begin{abstract}
This paper investigates the development of courses in computing and use of computers in education in universities (from the 1930s) and schools (from the 1970s) in Victoria, Australia. The paper describes the significant events of the era and investigates the relationship between the development of courses in the universities and the more vocationally oriented Colleges of Advanced Education (CAE): did one follow from the other? It also investigates the extent of the influence of the universities and CAEs on school computing.
\end{abstract}

Keywords: History, Computers in Education, History of University Computing, History of School Computing, Victoria.

\section{Introduction: Early Use of Computers in Australia}

In this paper we investigate the history of computers and education in both universities and schools in Victoria, Australia over the period from the 1930s to the 1990s. Primary and High School use of computers did not commence until the 1970s but prior to this there is a considerable and interesting history associated with the development of higher education courses relating to computing.

All of Australia's early computers were based in the universities with CSIRAC, Australia's first computer ${ }^{1}$ that was operational in 1949, in general use at the University of Sydney from 1951-1956 and later at the University of Melbourne until 1964, and SILLIAC in Sydney from 1954 [1]. From the mid-1950s a number of these computers were opened to general use and practical training in programming was introduced at the Universities of Melbourne, Sydney, and New South Wales (NSW). Early training courses, each of a few weeks duration, were offered in the programming techniques appropriate to each machine [2]. This was the beginning of the use of computers in education in Australia.

1 CSIRAC (or CSIR Mk1 as it was then called) was arguably the world's fourth of fifth digital electronic stored-program computer. 
Prior to the late 1980s Australia had a two-tiered system of higher education: 'Universities' and 'Colleges of Advanced Education' (CAE). After 1990, a series of mergers saw the end of the CAEs and the creation of a number of new universities. Naming of these institutions is, however, a little more complex as in the 1950s and 1960s many of the future CAEs were called 'Technical Colleges', and in the 1970s and 1980s some became 'Institutes of Technology'. It should be noted that in this paper Technical College, Institute of Technology and College of Advanced Education can all be taken to apply to institutions of essentially the same nature. This paper will investigate the relationship between the development of courses in the universities and the CAEs: did one type follow from the other?

Significant educational computing in primary schools and high schools dates from the 1970s and came in two forms: teaching about computing and the use of computers to enhance learning in other subject areas. The paper will investigate the effect that the universities and CAEs had, or did not have, on each form of school computing, and how these forms of school computing related to each other.

The research described in this paper was qualitative in nature with data collected from published sources, interviews and personal observation.

\section{Computers in Education - Universities and Schools}

In Australia a number of distinct periods can be identified in the evolution of higher education and school courses in computing towards those we see today [3].

- 1930s-1950

○ From 1935: Courses in Technical Colleges on the use of punched-card Accounting/Tabulating Machines

- 1950-1959

○ From the early 1950s: University first generation computing using mainframes with punched-cards.

- Computing courses were typically offered in Departments of Mathematics and had a considerable mathematical influence.

- 1960-1969

- 1965: The Commonwealth Government Programmers-in-Training scheme. Beginnings of mini-computer based computing courses in the CAEs.

- $1970-1979$

- Growth of CAE courses, typically using mini-computers and punchedcards.

- Beginnings of school computing using mark-sense cards on minicomputers located at local universities.

- 1980-1989

○ 1980-1990: Introduction of the micro-computer.

- Courses at universities and CAEs move increasingly to the use of microcomputers.

- Rapid increase in the use of micro-computers in schools.

- 1990 to the present

Each of these periods will now be described in detail. 


\subsection{The Period from 1930s-1950}

From about 1935, several courses began to be offered in Victorian Technical Colleges in the use of punched-card operated accounting/tabulating machines. These courses were very much business-oriented in outlook and whilst not what we would now call computing courses, did lay some ground work for future courses in business computing [4].

The first courses in Theory of Computation, Computing Practices and Theory of Programming, what we might now call aspects of Computer Science, were introduced in 1947 by Trevor Pearcey (the principal designer of CSIRAC) in the Department of Mathematics at the University of Sydney. At this point, computing was very much a mathematical study. At that time, of course, to use a computer at all required knowledge of programming, and it was several years before computing was seen anywhere other than Statistics and Mathematics Departments [5, 6].

Although Australia at that time, along with the UK and USA, was in the forefront, the situation in other countries was similar and much has been written on this [7-12].

\subsection{The Period from 1950-1959}

In 1956 CSIRAC moved from Sydney and was re-located at the University of Melbourne. Programming courses were given regularly in Melbourne from 1956, and in 1959 a subject in Numerical Methods and Computing was developed (delivered by Pearcey) in the BA course in Pure Mathematics. During this period several university computer systems were opened to general use and courses involving practical training in programming and the application of computers were introduced in the universities of Melbourne, Sydney and NSW. In 1959 the first post-graduate diploma in Numerical Analysis and Automatic Computing was offered by the University of Sydney [13].

\subsection{The Period from 1960-1969}

In the early 1960s most educational institutions, and particularly the Technical Colleges, were still teaching about punched-card operated accounting machines. During this period, however, a great deal happened in relation to computing in higher education, perhaps the most important being the decision (taken in the late 1950s) by the Australian Commonwealth Government to computerise the operation of the Department of Defence and the Post Master General's Department (PMG), so creating a massive requirement for trained computing personnel [14].

At this time the universities were only just starting to come to grips with the issue of whether computing was a part of mathematics or should be considered as a new discipline [3]. With courses which were quite theoretical in nature, relatively few staff and sparse facilities, the universities were largely unprepared for the demands of the Commonwealth which needed courses with a substantial component that was vocational in nature. The universities had little interest in providing such courses [4] so in 1960 the Australian Government's Commonwealth Public Service Board set up the Programmers in Training (PIT) scheme initially of twelve weeks duration as a temporary 
measure to alleviate the severe shortage of programmers and other computer professionals in Commonwealth Government departments. The PIT courses were oriented towards training staff for the establishment and running of commercial and administrative computing applications.

Although regarding this training as successful in providing a 'crash computing course' the Public Service Board recognised a need to set up longer courses and began designing a full-year long Programmer-in-Training (PIT) course. The first of these PIT courses ran in 1965 and initially drew upon the Defence and PMG staff experience with both computerised, and existing non-computerised administrative systems. Maynard, who was then an O\&M${ }^{2}$ Inspector with the PMG, (1990) describes this course as a "double-decker sandwich course of one year duration combining periods of formal classroom education with on-the-job training" [4]. The PIT courses took over 20 hours/week of formal class time for a year and operated initially in Canberra and Melbourne (Maynard, 1990; Pearcey, 1988). The 46 week course covered the topics: introduction to the course and the service; computer equipment and techniques, computer mathematics (statistics), programming, systems analysis and design.

One of the first educational institutions in Australia to adopt business computing as a priority was Caulfield Technical College ${ }^{3}$ offering, in 1961, a Certificate of Accounting (DP) course and by 1967 a Diploma of Business Studies (Data Processing). Maynard, now a lecturer at PIT, [14] suggests that these courses were the forerunner of many of today's courses in Information Systems [3]. From this period on, university and other higher education computing courses were seen to become 'respectable' and were soon widely available. In 1962 Royal Melbourne Institute of Technology (RMIT) got its first computer - an Elliot 803, and in 1963 short evening post-diploma courses were offered at Caulfield Institute of Technology (formerly Caulfield Technical College) on Punched-Card Systems, Accounting Machine Applications, Commercial Electronic Data Processing and Principles of Analogue Computing. Surprisingly, in that same year, a survey suggested that businesses in Victoria believed that they would need only ten programmers in the next ten years [5] - perhaps there would be no need for all these new computer professionals!

Other courses were introduced at this time at Caulfield Institute of Technology, Bendigo Institute of Technology and Footscray Institute of Technology. These courses had titles like: Diploma of Information Processing, Post Diploma of Electronic Computing and Associate Diploma in Accountancy (Data Processing), Certificate in Electronic Data Processing (Operating and Coding), Diploma of Business Studies (Data Processing), Information Processing Diploma and an Electronic Computing Post Diploma $[15,16]$.

In the university sector, the University of Melbourne established a Department of Information Science [5] and offered courses in the Theory of Computation, and Monash University set up a Department of Information Science in the Science Faculty and offered Computer Science in its science degree. Monash's first computer was a 7,000 word Sirius with two sets of Ferranti/Creed model 75 tape editing equipment [17-19]. Changes in technology then meant that such courses typically moved from

\footnotetext{
2 Organisation and Methods

3 After a series of amalgamations Caulfield Technical College became Caulfield Institute of Technology and then went on to become a part of Monash University.
} 
delivery on an institution's mainframe to one of its new mini-computers producing a fundamental change in the content and availability of computing courses.

\subsection{The Period from 1970-1979}

In 1970 the Commonwealth Public Service Board decided to hand over the running of PIT courses to Caulfield Institute, Bendigo Institute, Canberra CAE and NSW Institute of Technology (Maynard 1990). According to Greig \& Levin [20]:

"The Public Service Board believed that the increasing use of sophisticated computer equipment at the colleges and their need for increasing numbers of trained 'computer personnel' made such a development desirable. ' [20:7]

The 'new' PIT scheme commenced operation at the CAEs in 1971. This was very important as it could be seen as the beginning of higher education courses of business computing and information systems.

\subsubsection{University and CAE Computing Courses}

From the early 1970s computing courses began to proliferate in Universities and CAEs, but at this time Chisholm Institute of Technology (the former Caulfield Technical College), like most other universities and CAEs, was still using punched-cards for students to enter their programs. It was not until the end of this decade that microcomputers began to enter higher education institutions [14].

In 1971 the 'new' Programmer-in-Training programme supported 235 trainees Australia-wide [21]. This new scheme had the wider objective of providing trained computer personnel to industry as well as the Commonwealth and State Public Service [5] and comprised both full-time classes and on-the-job training.

Although teaching in Computer Science began in Australia's universities of the 1950s, CAEs courses in Business Computing only commenced in the 1960s. The growth in CAE courses owed a great deal to the Commonwealth Programmer-inTraining (PIT) scheme which became the model for many future courses in Business Computing. The reluctance of the universities to become involved in what they saw as little more than vocational training opened the way for the CAEs to develop this curriculum area. Juliff, an academic at Caulfield Institute of Technology and later Victoria College, [15] suggests that university Computer Science was, at this time, taught mostly by people whose primary love was mathematics and that was the flavour they gave to their courses. They saw no need for courses to be relevant to the real world. The PIT scheme, on the other hand, was very business-oriented in design. It is thus clear that courses in Business Computing in the CAEs did not diverge from university Computer Science courses, but developed from those of the PIT scheme.

\subsubsection{Computing in Schools}

It was in the early 1970 s that school computing began when a small number of computers started to appear in Australian schools, typically resulting from the exposure of particular teachers to computing during their university studies. In 1972, for example, Burwood High School was loaned a PDP-8 computer by Digital Equipment [22] and the following year McKinnon High School received an Innovations Grant to enable the purchase of an $8 \mathrm{k}$ Wang computer also used by Teletype terminal access by Box 
Hill High School. These early computers were used by mathematics departments almost exclusively for the teaching of programming [22].

The biggest impact on schools at this time was introduction of the Monash Educational Computer System (MONECS). Before the advent of the PC it was impossible for an average school to have hands-on access to a computer. In 1974 a group at Monash University produced a system using mark-sense cards that allowed a class of 30 students to each get two program runs in a one-hour period [23]. The MONECS system was used to teach programming in FORTRAN or BASIC. At this stage schools saw computing as a branch of mathematics concerned with algorithm design.

Another development at this time was experimentation by the Victorian Technical Schools with use of Control Data's 'PLATO System' [24] for computer-assisted instruction, mainly for the training of apprentices. The system was, however, very expensive and its use did not proceed.

The arrival of the Apple II in 1977 saw the end of this period and the beginning of real advances in the use of computers in schools. Watsonia High School (where we were both teaching at the time) was one of the first high schools in Australia to obtain an Apple II computer [25]. At around \$2,000 for a 16k Apple II that used a tape drive (not supplied - you simply used your own cassette recorder) and a television (also not supplied) as a monitor the Apple II was (almost) affordable for schools. This was before the days of the ascendancy of the IBM PC, MS-DOS and the Apple Macintosh and schools made use of the Apple II and a variety of other micro-computers.

In 1978-1979 the Victorian Education Ministry [22, 26] produced a plan for the introduction of computers to schools and it was not long before several different streams of computer education emerged:

- Computers across the curriculum - computer use in different subject areas

- Computer Science

- Programming in mathematics

- Use of word processors by secretarial studies students

- Logo

- Computer industry/business training in Technical Schools [27].

In the late 1970s the Education Department's Secondary Mathematics Committee recognised the potential of computers in mathematics and other aspects of education and set up a Computer Travelling Road Show consisting of teachers with some knowledge of computing who travelled around the state in groups of two or three, normally bringing a 16k Apple II with tape drive. Visits to schools around the State were used to promote the use of computers all subject areas. Each demonstration by the 'Road Show' was typically to an entire teaching staff, with students being sent home for the day. Another important school curriculum support mechanism used by the Victorian Ministry of Education in the late 1970s and early 1980s was the Regional Subject Consultants who were practicing school teachers seconded from their schools, usually on a part-time basis [28]. They rarely had any interaction with school students, working instead to support the work of teachers and school principals in using computers. 


\subsection{The Period from 1980-1989}

In 1980 Chisholm Institute (like most other tertiary institutions) was still using a minicomputer, with terminals for students to enter their programs. Around this time, however, traditional Business Computing (later Information Systems) curricula were beginning to develop in the CAEs and most courses had a core of similar topics which were typically based around subjects related to systems analysis and design, database design, business programming (which was typically done using third generation such as BASIC, COBOL or Pascal) and systems implementation. Many of these courses also had an introductory computer networking unit which was probably the most technical and close to the discipline of Computer Science. Subjects handling computer architecture probably delved well into the realm of Computer Science and were often electives. By 1985 micro-computer adoption in tertiary institutions was widespread [29].

\subsubsection{Computer Awareness Courses in Schools}

In 1980 the Secondary Computer Education Curriculum Committee was formed with a brief for the production of Computer Awareness course guidelines, the investigation of Computer Science as a discipline, the publication of computer education articles, the collection, propagation of public domain software and the provision of in-service education [6].

Although in developed countries around the world today secondary school students are very 'aware' of information technology and its many use, this was not the case in the early to mid-1980s and Computer Awareness courses sought to address the twin problems of poorly prepared teachers and a mystical understanding of the nature of computers. Such a course would typically cover the following topics:

- How a computer works, computer programming, history of computing

- Business and commercial uses of information technology

- The social implications of increased use of computers.

Interestingly, although teachers of Mathematics were the prime movers in these early days, mathematics classes did not embrace computers into the later 1980s. What appears to have happened is that programmable calculators were seen as more relevant to teaching mathematics. In many cases the Mathematics teachers interested in school computing moved over to the teaching of computing: Computer Awareness or Computer Science, and gave up any attempt to use computers in mathematics, which today would be one of the subject areas making least use of computers.

The role of mathematics in the adoption of computers in schools appears to be a common phenomenon around the world as one article from The Netherlands notes:

In addition in the participating schools mainly math teachers appeared to

be the early adopters of the new subject, because of their knowledge, expe-

rience and interest in information technology [30].

Authors from many countries including UK [31-33], Ireland [34], Israel [35], The Netherlands [30, 36], USA [37], Finland [38] and Poland [39] make similar comments. This is just a small sample of many articles by authors that remark on the role and future of mathematics and mathematics teachers in the early adoption of computers in schools in their own countries. 


\subsubsection{Computer Science Courses}

In 1981, as a result of several years of effort by a group of CAE and university academics, Computer Science was first offered as a Year-12 Higher School Certificate (HSC) subject in Victoria, although personnel from the Education Department had little involvement in determining the nature and content of this subject [40].

It is interesting to look at reactions to this new subject from tertiary institutions, schools and the general public. Melbourne and Monash universities, which saw themselves as guardians of academic standards, rejected the subject, not allowing its inclusion in admission scores for their courses. Their stated reason for this was that the component of assessment allotted to formal examination was only 35\% (rather than the more typical 50\%). When pressed, some academics from these institutions admitted that they considered the subject of little serious academic worth, and 'not an appropriate subject to study at a secondary school level'. The newer universities (Deakin and La Trobe) and the CAEs did accept it as a valid study. Parents, students and employers also readily accepted the value of HSC Computer Science [40].

Teachers, however, were not universally in favour of the new subject with some claiming it to be an elitist academic subject, too difficult for some students. Others noted that the ratio of girls to boys taking Computer Science was low and suggested that it was becoming a boys' subject. Perhaps the most damaging criticism though came from those teachers who claimed that the presence of a specialist subject detracted from the use of computers across the curriculum as it put too great a strain on school computing facilities.

\subsubsection{Support for School Computing from the Commonwealth Government}

In April 1983, the Federal Minister for Education and Youth Affairs announced that the Government would set up a National Advisory Committee on Computers in Schools. In its report Teaching Learning and Computers in Schools [41] the Committee made comprehensive recommendations covering curriculum development, professional development, support services, software/courseware, hardware and organisation. The Commonwealth also provided $\$ 18.7 \mathrm{~m}$ in funds to support these activities.

In the early 1980s the Victorian Education Department created the State Computer Education Centre (SCEC) to support and control school computing. Financed through the Commonwealth and State Computer Education Programs, SCEC was set up in 1985 with twenty-seven full-time professional positions. SCEC played a significant role in setting the direction of educational computing in Victoria for the next three years: it developed policy, produced curriculum documents, evaluated and distributed educational software, evaluated computer hardware and produced the 'recommended list' of computer systems for use in schools, facilitated interstate contacts and the sharing of resources, conducted professional development activities and generally coordinated computer education in the state [26].

\subsection{The Period from 1990 to the present}

In relation to senior secondary school curriculum, a review in the early 1990s replaced the Higher School Certificate by the Victorian Certificate of Education (VCE) that extended over Years 11 and 12. This also saw the demise of Year 12 Computer Science and its replacement by three new subjects: Information Processing and Man- 
agement, Information Systems and Information Technology in Society. An additional new subject: Information Technology was offered only at Year 11.

In the 1990s computing curriculum continued to grow in the universities and at the start of this period 1,400 students were studying computing related subjects in Victorian universities. What happened in universities and schools after this time with the advent of the Internet, Web, on-line learning, laptops and smart phones is beyond the scope of this paper.

\section{Conclusion}

In this paper the three strata of the Victorian education system have been traced in the decades from 1930 to the early 1990s. It can be readily seen from this analysis that universities were the original users of electronic computers but that they had little influence on the vocationally based CAE sector. It can also be seen that the forces shaping school computing were again largely divorced from the influence of the tertiary sector. Schools in Victoria embraced the freedom afforded by the relatively low cost micro-computers and early work of pioneers within schools and the Ministry of Education had the effect of broadening the use of computers in schools beyond the rather restricted initial uses in universities.

Of course this is a little simplistic. Teachers mostly became enthused due to initial contact with computers in their university pre-service education and we have not mentioned the significant in-service education provided by Faculties of Education in the 1980s. Within these limitations it can be said that the decentralisation of school based curriculum development in the 1970s and 1980s in Victoria had a marked effect on the direction of school computing. It can also be concluded that the divergent origins of computing in CAEs and Universities lead to a distinct divergence between Computer Science at Universities and Information Systems in CAEs.

\section{References}

1. McCann, D. and Thorne, P., The Last of the First - CSIRAC: Australia's First Computer. 2000, Melbourne: The University of Melbourne.

2. Bennett, J.M., Broomham, R., Murton, P.M., Pearcey, T., and Rutledge, R.W., eds. Computing in Australia. The Development of a Profession. 1994, Hale \& Iremonger (in conjunction with the Australian Computer Society): Sydney.

3. Tatnall, A., Curriculum Cycles in the History of Information Systems in Australia. 2006, Melbourne: Heidelberg Press.

4. Tatnall, A., A Curriculum History of Business Computing in Victorian Tertiary Institutions from 1960 - 1985, in Education. 1993, Deakin University: Geelong.

5. Pearcey, T., A History of Australian Computing. 1988, Melbourne: Chisholm Institute of Technology.

6. Tatnall, A., The Growth of Educational Computing in Australia, in History, Context, and Qualitative Methods in the Study of Education, Goodson, I., F. and Mangan, J.M., Editors. 1992, University of Western Ontario, Canada.: London, Ontario. p. 207-248. 
7. Bonfanti, C., Information Technology in Italy: The Origins and the Early Years (1954 - 1965), in Reflections on the History of Computing: Preserving Memories and Sharing Stories, Tatnall, A., Editor. 2012, Springer: Heidelberg.

8. Kovacs, G., Hungarian Scientists in Information Technology, in Reflections on the History of Computing: Preserving Memories and Sharing Stories, Tatnall, A., Editor. 2012, Springer: Heidelberg.

9. Fet, Y., From the History of Russian Computer Science, in Reflections on the History of Computing: Preserving Memories and Sharing Stories, Tatnall, A., Editor. 2012, Springer: Heidelberg.

10. Sanders, N., A Possible First Use of CAM/CAD, in Reflections on the History of Computing: Preserving Memories and Sharing Stories, Tatnall, A., Editor. 2012, Springer: Heidelberg.

11. Deane, J., Australia's WREDAC - it was Rocket Science, in Reflections on the History of Computing: Preserving Memories and Sharing Stories, Tatnall, A., Editor. 2012, Springer: Heidelberg.

12. Lawson, H., Experiences and Reflections, in Reflections on the History of Computing: Preserving Memories and Sharing Stories, Tatnall, A., Editor. 2012, Springer: Heidelberg.

13. Pearcey, T., The Origins of Modern Computers, in Computing in Australia. The Development of a Profession, Bennett, J.M., Broomham, R., Murton, P.M., Pearcey, T., and Rutledge, R.W., Editors. 1994, Hale \& Iremonger (in conjunction with the Australian Computer Society): Sydney. p. 1-9.

14. Maynard, G., Interview on the History of Business Computing. 1990: Melbourne.

15. Juliff, P., Interview on Business Computing Curriculum. 1990: Melbourne.

16. Juliff, P., Interview on Business Computing Curriculum. 1992: Melbourne.

17. Davey, W. and Parker, K., Turning Points in Computer Education, in History of Computing. Learning from the Past, Tatnall, A., Editor. 2010, Springer: Heidelberg. p. 159-168.

18. Lukaitis, A., Lukaitis, S., and Davey, W., The Birth of Information Systems, in History of Computing. Learning from the Past, Tatnall, A., Editor. 2010, Springer: Heidelberg. p. 206-215.

19. Ainsworth, A.B. Monash University's First Computer. 2009 January 2010]; Available from: http://www.infotech.monash.edu.au/about/projects/museum/papers/firstcomputer-at-monashuniversityv7.pdf.

20. Greig, J. and Levin, P., Computing at Chisholm: The First Twenty Five Years, 1965-1989. 1989, Melbourne: Chisholm Institute of Technology.

21. Philcox, R., The Commonwealth Public Service Board and the Introduction of Computer Technology, Early Australian Computer Systems. 1978, University of Melbourne: Melbourne. p. 208-224.

22. Salvas, A.D., Personal communication. 1985: Melbourne.

23. Monash Computing Museum. MONECS Deamon Educational Computer system. [Web] 2003 Feb 2004]; Available from: http://www.csse.monash.edu.au/museum/.

24. Plato Learning. History of Plato Learning. 2004 Feb 2004]; Available from: http://www.plato.com/aboutus/company_history.asp. 
25. Tatnall, A. and Davey, W., Making History relevant Through the Provision of Education, Stories and Interactive Experiences, in Making the History of Computing Relevant, Tatnall, A., Blyth, T., and Johnson, R., Editors. 2013, Springer: Heidelberg, Germany. p. 35-44.

26. Tatnall, A., The Role of the State Computer Education Centre of Victoria, in MA (preliminary) thesis, Education, Editor. 1985, Deakin University: Geelong.

27. Tatnall, A. and Davey, W., Streams in the History of Computer Education in Australia, in History of Computing in Education, Impagliazzo, J. and Lee, J.A.N., Editors. 2004, Kluwer Academic Publishers / IFIP: Assinippi Park, Massachusetts. p. 83-90.

28. Tatnall, A., Schools, Students and Curriculum in Victoria in the 1970s and 1980s, in Reflections on the History of Computing in Education: Early Use of Computers and Teaching about Computing in Schools, Tatnall, A. and Davey, B., Editors. 2014, Springer: Heidelberg, Germany. p. 245-264.

29. Tatnall, A., Innovation and Change in the Information Systems Curriculum of an Australian University: a Socio-Technical Perspective. 2000, Central Queensland University: Rockhampton.

30. Voogt, J. and ten Brummelhuis, A., Information Literacy in the Netherlands: Rise, Fall and Revival, in Reflections on the History of Computing in Education: Early Use of Computers and Teaching about Computing in Schools, Tatnall, A. and Davey, B., Editors. 2014, Springer: Heidelberg, Germany.

31. Demant, D., Whatever You Do ... . Don't Put the Computer Room near the Maths Department! or, I was an Early Adopter, an Enthusiastic Disseminator, but Now, in Reflections on the History of Computing in Education: Early Use of Computers and Teaching about Computing in Schools, Tatnall, A. and Davey, B., Editors. 2014, Springer: Heidelberg, Germany.

32. Millwood, R., From Mathematics Teacher to Computer Assisted Learning Researcher, in Reflections on the History of Computing in Education: Early Use of Computers and Teaching about Computing in Schools, Tatnall, A. and Davey, B., Editors. 2014, Springer: Heidelberg, Germany.

33. Passey, D., Early Uses of Computers in Schools in the United Kingdom: Shaping Factors and Influencing Directions, in Reflections on the History of Computing in Education: Early Use of Computers and Teaching about Computing in Schools, Tatnall, A. and Davey, B., Editors. 2014, Springer: Heidelberg, Germany.

34. Leahy, D. and Dolan, D., The Introduction of Computers in Irish Schools, in Reflections on the History of Computing in Education: Early Use of Computers and Teaching about Computing in Schools, Tatnall, A. and Davey, B., Editors. 2014, Springer: Heidelberg, Germany.

35. Barta, B.-Z., Shapiro, L., Millin, D., and Engel, E., The Rise of Information and Communication Technology Era in the Israeli Educational System, in Reflections on the History of Computing in Education: Early Use of Computers and Teaching about Computing in Schools, Tatnall, A. and Davey, B., Editors. 2014, Springer: Heidelberg, Germany.

36. Zwaneveld, B. and Schmidt, V., The Dutch Situation: An Ever Continuing Story, in Reflections on the History of Computing in Education: Early Use of 
Computers and Teaching about Computing in Schools, Tatnall, A. and Davey, B., Editors. 2014, Springer: Heidelberg, Germany.

37. Parker, K. and Davey, B., Computers in Schools in the USA: a Social History, in Reflections on the History of Computing in Education: Early Use of Computers and Teaching about Computing in Schools, Tatnall, A. and Davey, B., Editors. 2014, Springer: Heidelberg, Germany.

38. Koivisto, J., Computers in Education in Finland, in Reflections on the History of Computing in Education: Early Use of Computers and Teaching about Computing in Schools, Tatnall, A. and Davey, B., Editors. 2014, Springer: Heidelberg, Germany.

39. Sysło, M.M., The First 25 Years of Computers in Education in Poland: 1965 1990, in Reflections on the History of Computing in Education: Early Use of Computers and Teaching about Computing in Schools, Tatnall, A. and Davey, B., Editors. 2014, Springer: Heidelberg, Germany.

40. Tatnall, A. and Davey, W., The Life and Growth of Year 12 Computing in Victoria: An Ecological Model, in History of Computing: Learning from the Past, Tatnall, A., Editor. 2010, Springer: Heidelberg. p. 124-133.

41. Commonwealth Schools Commission, Teaching, Learning and Computers. Report of the National Advisory Committee on Computers in Schools. 1983, Commonwealth Schools Commission: Canberra. 